\title{
KLASIFIKASI DATA MAHASISWA MENGGUNAKAN METODE K- MEANS UNTUK MENUNJANG PEMILIHAN STRATEGI PEMASARAN
}

\author{
Totok Suprawoto \\ Sistem Informasi, STMIK AKAKOM Yogyakarta \\ e-mail : totok@akakom.ac.id, suprawoto.totok@gmail.com
}

\begin{abstract}
ABSTRAK
Analisis cluster merupakan teknik data mining yang bertujuan untuk mengidentifikasi suatu kelompok dari objek yang memiliki karakteristik yang sama. Jumlah kelompok yang dapat diidentifikasi tergantung pada sejumlah data dan jenis dari objeknya. K-Means adalah salah satu metode clustering data yang dibagi kedalam bentuk satu atau lebih cluster/kelompok yang memiliki karakteristik sama. Clustering data mahasiswa menggunakan metode $K$-Means, terdiri dari nilai rerata ujian nasional (UN) dan indeks prestasi kumulatif (IPK) mahasiswa. Penelitian ini menggunakan data mahasiswa angkatan 2014/2015. Kemudian diperoleh kesimpulan bahwa kelompok mahasiswa dengan nilai rerata UN yang rendah memiliki pengaruh terhadap prestasi akademik mahasiswa yang rendah pada jenjang diploma-3( D-3) dan strata-1 (S-1). Jika mahasiswa memiliki nilai UN yang tinggi maka prestasi akademik mahasiswa juga tinggi pada semua jenjang. Dari hasil pengelompakan berdasarkan daerah asal sekolah IPK rata-rata yang tertinggi berasal dari propinsi Daerah Istimewa Yogyakarta (DIY) dan Jawa Tengah (Jateng).
\end{abstract}

Kata kunci: K-Means, Cluster, IPK, Nilai Rerata UN

\begin{abstract}
Cluster analysis is data mining techniques that aim to identify a group of objects that have the same characteristics. The number of groups that can be identified depending on a number of data and the type of object. K-Means clustering is a method of data which is divided into the form of one or more clusters / groups that have the same characteristics.

The use of K-Means method to perform clustering of students based on the average value of the UN andstudents GPA. Profile data sample of students of 2014/2015 showed that the group of students with a lower average value of the UN that has an influence on students' academic achievement is low $(6.30,1.87)$ and the levels of D-3 $(6.45,1.78)$ for S1, being the value of the UN the higher the academic achievement of students is also high $(5.66,3.12)$ for levels of D-3 and (8.19, 3.31) to S1.

Results from this study can be concluded that the higher the average value of the UN, the results of academic achievement as measured from it GPA's also higher. From the results based on region of school GPA highest come from Yogyakarta Central Java.
\end{abstract}

Keywords: K-Means, Cluster, GPA, Average Value of UN

\section{PENDAHULUAN}

$\mathrm{P}$ erguruan tinggi sebagai institusi pendidikan telah memiliki data akademik dan administrasi dalam jumlah yang sangat besar, namun hanya sebagian kecil data tersebut dimanfaatkan (khususnya dalam penyusunan evaluasi diri). Data akademik mahasiswa merupakan data yang dihimpun dari hasil kegiatan proses belajar mengajar selama mengikuti studi di suatu perguruan tinggi. Data tersebut antara lain: data pribadi mahasiswa, data rencana studi, dan data hasil studi (nilai dan indeks prestasi). Disamping itu, bagian admisi pada setiap awal tahun akademik melakukan rekrutmen calon mahasiswa baru. Data mahasiswa baru yang dihimpun pada saat pendaftaran dan/atau registrasi berupa nilai ujian nasional (UN) rata-rata dan/atau nilai hasil tes masuk perguruan tinggi. Jumlah data yang terakumulasi dari tahun ke tahun perlu dilakukan analisis untuk dapat membuka peluang dihasilkannya informasi yang berguna dalam pembuatan alternatif keputusan bagi manajemen perguruan tinggi.

Untuk menarik minat calon mahasiswa yang lebih banyak, diperlukan strategi promosi yang tepat, antara lain: asal sekolah, prestasi akademik, lokasi tempat tinggal, tren keminatan calon mahasiswa, kemampuan calon mahasiswa (akademik dan/atau finansial), proses pembelajaran, serta prospek lulusan kedepannya.

Objek penelitian bersumber dari data mahasiswa yang telah melakukan registrasi di STMIK AKAKOM. Atribut data yang akan digunakan adalah nama mahasiswa, jurusan SLTA, nilai UAN, kota asal mahasiswa, program studi yang dipilih dan IPK. Hasil yang diperoleh dari penelitian ini diarapkan dapat menampilkan profil mahasiswa, keterkaitan antara nilai UN terhadap IPK mahasiswa, serta sebaran asal sekolahnya. Dari hasil analisis tersebut diharapkan dapat membantu pihak admisi perguruan tinggi dalam menyusun strategi promosi program studi yang menjadi target.

Penggalian informasi pada sebuah data yang berukuran besar (mempunyai jumlah record dan jumlah atribut yang cukup banyak) tidak dapat dilakukan dengan mudah. Teknologi data mining merupakan salah satu alat bantu untuk penggalian data pada basis data berukuran besar dengan spesifikasi kerumitan tinggi dan telah banyak 
digunakan pada lingkungan aplikasi bisnis seperti perbankan, provider telekomunikasi, perusahaan pertambangan, perminyakan, dan lain-lain [1]. Clustering merupakan salah satu teknik data mining yang berfungsi melakukan pengelompokan sejumlah data atau objek ke dalam cluster (group) sehingga setiap cluster akan berisi data yang semirip mungkin dan berbeda dengan objek dalam cluster yang lainnya. Teknik klasifikasi merupakan pendekatan fungsi klasifikasi dalam data mining yang digunakan untuk melakukan prediksi atas informasi yang belum diketahui sebelumnya. Beberapa algoritma yang dapat digunakan antara lain adalah algoritma Decission Tree C.45, Artificial Neural Networks (ANN), K-Nearest Neighbor (KNN), algoritma Naive Bayes, Neural Network serta algoritma lainnya.

Klasterisasi merupakan teknik atau metode untuk mengelompokkan sejumlah besar data menjadi suatu bagianbagian kecil data yang mempunyai atribut kemiripan dalam sifat, letak, ciri atau filter lain yang telah ditentukan. Teknik atau metode klasterisasi dapat dikelompokkan menjadi dua kategori besar, yaitu : (1) Metode Hirarki (Hierarchical Clustering) dan (2) Metode Non-Hirarki/Partisi (Partitional Hierarchical). Referensi [1] menunjukkan bahwa Algoritma K-Modes merupakan metode pengembangan dari K-Means yang mampu mengelompokkan data kategorikal dan menghasilkan klaster yang lebih stabil dengan waktu komputasi yang lebih singkat daripada metode K-Means.

Teknik klasifikasi merupakan pendekatan untuk menjalankan fungsi klasifikasi dalam data mining yaitu untuk menggolongkan data. Teknik klasifikasi ini dapat pula digunakan untuk melakukan prediksi atas informasi yang belum diketahui sebelumnya. Beberapa algoritma yang dapat digunakan antara lain adalah algoritma Decission Tree C.45, Artificial Neural Networks (ANN), K-Nearest Neighbor (KNN), algoritma Naive Bayes, Neural Network serta algoritma lainnya. Beberapa penelitian yang menggunakan teknik data mining pada data set akademik dan kemahasiswaan telah banyak dilakukan, antara lain [1] melakukan penelitian untuk mengklasifikasi kinerja akademik mahasiswa dengan menggunakan algoritma Supervised Learning In Quest (SLIQ) dan [2] dalam penelitian mengenai perancangan aplikasi K-Means untuk pengelompokan mahasiswa berdasarkan frekuensi kunjungan ke perpustakaan dan IPK.

Perbedaan dengan penelitian [2] adalah atribut data, profil yang dihasilkan, dan kegunaan dari hasil analisisnya. Sedangkan perbedaan dengan [3] terletak pada metode maupun profil yang dihasilkan, meskipun dari dua peneliti tersebut objeknya sama yaitu data mahasiswa. Penelitian ini difokuskan pada analisis hasil klasterisasi menggunakan metode K-Means untuk mengelompokkan sejumlah data dengan variabel: kota asal, nilai UAN dan IPK lulusan. Sumber data berasal dari bagian akademik dan admisi STMIK AKAKOM Yogyakarta.

\section{METODE}

Penelitian ini menggunakan teknik klasifikasi dengan K-Means untuk mengelompokkan data kategorikal hingga menghasilkan klaster yang lebih stabil. Selanjutnya melakukan analisis lebih mendalam terhadap hasil klasterisasi tersebut untuk membantu bagian admisi dalam menentukan kebijakan mengenai promosi program studi di lingkungan STMIK AKAKOM.

Analisis cluster merupakan salah satu teknik data mining yang bertujuan untuk mengidentifikasi sekelompok objek yang mempunyai kemiripan karakteristik tertentu yang dapat dipisahkan dengan kelompok objek lainnya, sehingga objek yang berada dalam kelompok yang sama relatif lebih homogen daripada objek yang berada pada kelompok yang berbeda. Jumlah kelompok yang dapat diidentifikasi tergantung pada banyak dan variasi data objek. Tujuan dari pengelompokan sekumpulan data objek ke dalam beberapa kelompok yang mempunyai karakteristik tertentu dan dapat dibedakan satu sama lainnya adalah untuk analisis dan interpretasi lebih lanjut sesuai dengan tujuan penelitian yang dilakukan. Model yang diambil diasumsikan bahwa data yang dapat digunakan adalah data yang berupa data interval, frekuensi dan biner. Set data objek harus mempunyai variabel dengan tipe yang sejenis tidak campur antara tipe yang satu dengan lainnya.

Algoritma K-Means dimulai dengan pemilihan secara acak K, yang merupakan banyaknya kluster yang ingin dibentuk. Kemudian ditetapkan nilai-nilai K secara random, untuk sementara nilai tersebut menjadi pusat dari kluster atau biasa disebut dengan centroid/mean. Selanjutnya dihitung jarak dari setiap data yang ada terhadap masing-masing centroid menggunakan rumus yang sudah disediakan hingga diketemukan jarak yang paling dekat dari setiap data dengan centroid. Klasifikasi setiap data berdasarkan kedekatannya dengan centroid.

\section{A. Pengumpulan Data}

Pengumpulan data dilakukan melalui penghimpunan data mahasiswa angkatan 2014/2015 yang bersumber dari bagian akademik dan admisi. Data dari bagian akademik meliputi: nomor induk mahasiswa (NIM), nama, dan IPK, sedang data dari admisi, meliputi: NIM, nama, asal sekolah, kota asal, dan nilai UN rata-rata. Selanjutnya kedua jenis data diintegrasikan kedalam satu file. Data dipisahkan berdasarkan jenjang studi yaitu D-3 dan S-1, selanjutnya hasil integrasi dilakukan cleaning data, untuk memperoleh data yang valid. 
Metode K-Means digunakan untuk mengelompokkan data ke dalam beberapa kelompok, data dalam satu kelompok mempunyai karakteristik yang sama dan mempunyai karakteristik yang berbeda dengan data dari kelompok yang lain. Metode ini berusaha meminimalkan variasi antar data yang ada di dalam suatu cluster dan memaksimalkan variasi data yang ada di cluster lainnya.

\section{B. Analisis}

Untuk menentukan cluster, sebarang objek atau elemen pertama dapat dipilih untuk dijadikan sebagai titik tengah (centroid point) cluster. Algoritma metode K-Means selanjutnya akan melakukan pengulangan langkahlangkah berikut sampai terjadi kestabilan (tidak ada objek yang dapat dipindah-kan):

1) Menentukan koordinat titik tengah setiap cluster,

2) Menentukan jarak setiap objek terhadap koordinat titik tengah,

3) Mengelompokkan objek-objek tersebut berdasarkan pada jarak minimumnya.

4) Tentukan pusat cluster baru

5) Apakah ada selisih antara cluster lama dengan cluster baru?, Jika masih ada kembali ke langkah-1, jika tidak lanjut kelangkah 6.

6) Selesai.

\section{Prosedur Pelaksanaan}

Prosedur pelaksanaan yang dilakukan dalam penelitian ini meliputi:

1) Menghimpun data yang bersumber dari bagian akademik dan admisi untuk mahasiswa jenjang D3 dan S1, selanjutnya diintegrasikan untuk dilakukan data cleaning.

2) Menentukan jumlah cluster yang akan diproses lebih lanjut dan menetapkan titik pusat dari masing-masing cluster

3) Selanjutnya langkah-langkah yang dilakukan adalah menyusun data-data yang akan diolah termasuk parameter dan alternatif yang akan dirangking, merancang dan memproses perhitungan menggunakan metode K-Means untuk mendapatkan nilai pengelompokan mahasiswa berdasar-kan Nila Rata-rata UN dan IPK.

4) Hasil proses yang telah dinyatakan valid selanjutnya dilakukan analisis yang dikaitkan dengan kelompok dari asal kota sekolahnya.

\section{A. Analisis Data}

\section{III.HASIL}

Data sampel awal yang digunakan dalam penelitian ini, untuk D-3 sebanyak 66 data, sedang S-1 sebanyak 336 data (perhitungan dalam lampiran). Data mahasiswa awal (sebelum dilakukan perhitungan menggunakan metode K-Means) dapat dilihat pada Tabel I.

TABEL I

DAFTAR DATA AWAL

\begin{tabular}{|c|c|c|c|c|c|c|}
\hline Mhs & NAMA MAHASISWA & NOMHS & ASAL SEKOLAH & KOTA SEKOLAH & RNIL & IPK \\
\hline 1 & ERVIN YOGA PRADANA & 143110001 & SMK MUHAMMADIYAH 3 & KOTA & 7.50 & 2.89 \\
\hline 2 & MUHAMMAD MUKHBIT & 143110002 & SMK MUHAMMADIYAH 3 & KOTA & 8.45 & 3.06 \\
\hline 3 & MUHAMMAD CAHYO NOR & 143110003 & SMAN 1 TURI & KAB. SLEMAN & 6.21 & 1.93 \\
\hline 4 & NANDA DWI SURYO PUTRO & 143110004 & SMK (STM) MUHAMMADIYAH & KAB. SLEMAN & 6.33 & 1.52 \\
\hline 5 & SEPTIAN SARIP HIDAYAT & 143110005 & MAS AL MUNIROH & KAB. & 6.88 & 1.85 \\
\hline 6 & SITI NUR AZIZAH & 143110006 & SMK (SMKK) KARYA RINI YHI & KAB. SLEMAN & 7.65 & 2.59 \\
\hline 7 & MUHAMMAD ALFIAN & 143110007 & SMAN 1 KARANGMOJO & KAB. WONOSARI & 6.85 & 2.43 \\
\hline 8 & DEVI RATNA WULANDARI & 143110008 & SMK MUHAMMADIYAH & KAB. WONOSARI & 8.20 & 3.20 \\
\hline 9 & YUSUF SAIFULLAH & 143110009 & SMK (SMEA) MA`ARIF 1 TEMON & KAB. KULON PROGO & 8.25 & 3.33 \\
\hline 10 & BAYU YOGA PRATAMA & 143110011 & SMA IKIP VETERAN NGEMPLAK & KAB. SLEMAN & 7.10 & 2.16 \\
\hline 11 & ANANG NUGROHO & 143110012 & SMK (STM) MUHAMMADIYAH 1 & KAB. KLATEN & 7.55 & 2.59 \\
\hline 12 & ANNISA FAUZIAH & 143110013 & KEJAR PAKET C KAB. SLEMAN & SLEMAN & 8.12 & 3.18 \\
\hline 13 & KORNELIA DELVIN & 143110014 & SMK YPK SERUI ( SMEA) & YAPEN WAR & 7.15 & 2.79 \\
\hline 14 & BENI WAHYU ADI & 143110015 & SMAN 1 SEDAYU & KAB. BANTUL & 6.95 & 2.79 \\
\hline 15 & DESI WULANDARI & 143110016 & SMA MUHAMMADIYAH 4 & KOTA & 6.85 & 2.46 \\
\hline 16 & MUHAMMAD IWAN NUR & 143110018 & SMK (STM) MUHAMMADIYAH 1 & KAB. WONOSARI & 5.58 & 3.41 \\
\hline 17 & SIGIT GALIH & 143110019 & SMAN 1 PUNDONG & KAB. BANTUL & 7.34 & 2.90 \\
\hline \multirow{2}{*}{\multicolumn{7}{|c|}{..}} \\
\hline .. & & & & & & \\
\hline 54 & SUNARTI & 143110028 & MAN LAB UIN YOGYAKARTA & BANTUL & 7.85 & 3.09 \\
\hline 55 & M. AGUNG JULIWANTO & 143110029 & SMA TUNAS BANGSA & KAB. INDRAGIRI & 6.20 & 1.88 \\
\hline 56 & MUHAMAD MUSLIH & 143110030 & SMK DIPONEGORO & KAB. SLEMAN & 7.18 & 2.73 \\
\hline 57 & INGGRIT SISWATI PUTRI & 143110031 & SMAN 1 MLATI & KAB. SLEMAN & 6.45 & 2.14 \\
\hline 58 & BIMA NUR ADITAMA & 143110032 & SMA GADJAH MADA & KOTA & 8.25 & 2.56 \\
\hline 59 & MUHAMMAD TAUFIQ & 143110033 & SMAN 1 TIDORE & KOTA TERNATE & 7.75 & 2.34 \\
\hline 66 & FARIZ RACHMAT & 143110034 & SMA MUHAMMADIYAH 7 & KOTA & 7.90 & 2.83 \\
\hline
\end{tabular}


Selanjutnya diproses menggunakan algoritma K-Means, dengan urutan langkah sebagai berikut.

1) Menentukan koordinat titik tengah setiap cluster,

2) Menentukan jarak setiap objek terhadap koordinat titik tengah,

3) Mengelompokkan objek-objek tersebut berdasarkan pada jarak minimumnya.

4) Tentukan pusat cluster baru

5) Apakah ada selisih antara cluster lama dengan cluster baru, Jika masih ada kembali ke langkah-1, jika tidak lanjut kelangkah 6.

6) Selesai.

\section{B. Iterasi-1}

1) Penentuan nilai awal titik tengah.

Langkah pertama, menentukan pusat cluster secara acak pada data awal yang ada di Tabel I. Cluster pertama yang akan digunakan dalam perhitungan adalah $\mathrm{C}_{1}(6.0,2.0)$, artinya Nilai Rerata UN pada pengelompokan pertama adalah 6.0 dan IPK mahasiswa sebesar 2.0. Cluster kedua $\mathrm{C}_{2}(7.5,3.0)$ dan cluster ketiga $\mathrm{C}_{3}(8.0,3.75)$.

2) Menghitung jarak objek ke centroid dengan menggunakan rumus jarak Euclid.

Perhitungan jarak mahasiswa pertama dengan pusat cluster pertama adalah:

$$
\mathrm{C}_{11}=\sqrt{(7.5-6.0)^{2}+(2.89-2.0)^{2}}=1.74
$$

Perhitungan jarak mahasiswa pertama dengan pusat cluster kedua adalah: $\mathrm{C} 12=\sqrt{(7.5-7.5) 2+(2.89-3.0) 2}=0.11$

Perhitungan jarak mahasiswa pertama dengan pusat cluster ketiga adalah: $\mathrm{C} 13=\sqrt{(7.5-8.0) 2+(2.89-3.75) 2}=0.99$

Perhitungan jarak mahasiswa kedua dengan pusat cluster pertama adalah: $\mathrm{C} 11=\sqrt{(8.45-6.0) 2+(3.06-2.0) 2}=2.67$

Perhitungan jarak mahasiswa kedua dengan pusat cluster kedua adalah: $\mathrm{C}_{12}=\sqrt{(8.45-7.5)^{2}+(3.06-3.0)^{2}}=0.95$

Perhitungan jarak mahasiswa kedua dengan pusat cluster ketiga adalah: $\mathrm{C}_{13}=\sqrt{(8.45-8.0)^{2}+(3.06-3.75)^{2}}=0.82$

Perhitungan jarak mahasiswa ketiga dengan pusat cluster pertama adalah: $\mathrm{C}_{11}=\sqrt{6.21-6.0)^{2}+(1.93-2.0)^{2}}=0.22$

Perhitungan jarak mahasiswa ketiga dengan pusat cluster kedua adalah: $\mathrm{C}_{12}=\sqrt{(6.21-7.5)^{2}+(1.93-3.0)^{2}}=1.68$

Perhitungan jarak mahasiswa ketiga dengan pusat cluster ketiga adalah: $\mathrm{C}_{13}=\sqrt{(6.21-8.0)^{2}+(1.93-3.75)^{2}}=2.55$

Perhitungan yang sama dilakukan untuk data ke empat hingga ke enam puluh enam. Hasil perhitungan dapat dilihat pada Tabel II.

\begin{tabular}{rccc}
\hline \hline \multirow{2}{*}{ Mhs Ke } & \multicolumn{3}{c}{ Cluster } \\
\cline { 2 - 4 } & $\mathrm{C} 1$ & $\mathrm{C} 2$ & $\mathrm{C} 3$ \\
\hline 1 & 1.74 & 0.11 & 0.99 \\
2 & 2.67 & 0.95 & 0.82 \\
3 & 0.22 & 1.68 & 2.55 \\
4 & 0.58 & 1.89 & 2.79 \\
5 & 0.89 & 1.31 & 2.21 \\
6 & 1.75 & 0.44 & 1.21 \\
7 & 0.95 & 0.86 & 1.75 \\
8 & 2.51 & 0.73 & 0.59 \\
9 & 2.61 & 0.82 & 0.49 \\
10 & 1.11 & 0.93 & 1.83 \\
11 & 1.66 & 0.41 & 1.24 \\
12 & 2.43 & 0.65 & 0.58 \\
13 & 1.40 & 0.41 & 1.28 \\
14 & 1.24 & 0.59 & 1.42 \\
15 & 0.97 & 0.85 & 1.73 \\
16 & 1.47 & 1.96 & 2.44 \\
17 & 1.61 & 0.19 & 1.08 \\
18 & 0.72 & 1.31 & 2.07 \\
19 & 2.30 & 0.65 & 0.90 \\
20 & 0.67 & 1.38 & 2.14 \\
21 & 0.87 & 1.78 & 2.45 \\
22 & 1.25 & 1.03 & 1.90 \\
\hline \hline
\end{tabular}

TABEL II.

\begin{tabular}{|c|c|c|c|c|c|c|c|}
\hline \multirow{2}{*}{ Mhs Ke } & \multicolumn{3}{|c|}{ Cluster } & \multirow{2}{*}{ Mhs Ke } & \multicolumn{3}{|c|}{ Cluster } \\
\hline & $\mathrm{C} 1$ & $\mathrm{C} 2$ & C3 & & $\mathrm{C} 1$ & $\mathrm{C} 2$ & C3 \\
\hline 23 & 1.51 & 0.33 & 1.15 & 45 & 2.38 & 1.16 & 1.55 \\
\hline 24 & 2.15 & 0.36 & 0.68 & 46 & 2.77 & 0.99 & 0.60 \\
\hline 25 & 0.23 & 1.72 & 2.60 & 47 & 0.24 & 1.96 & 2.79 \\
\hline 26 & 1.39 & 0.42 & 1.31 & 48 & 0.38 & 2.12 & 2.99 \\
\hline 27 & 0.47 & 1.36 & 2.23 & 49 & 2.42 & 0.70 & 0.78 \\
\hline 28 & 2.32 & 0.87 & 1.22 & 50 & 1.48 & 0.33 & 1.22 \\
\hline 29 & 1.78 & 0.71 & 1.43 & 51 & 1.46 & 0.35 & 1.25 \\
\hline 30 & 2.07 & 0.43 & 0.93 & 52 & 0.16 & 1.70 & 2.57 \\
\hline 31 & 2.76 & 1.02 & 0.76 & 53 & 0.65 & 1.87 & 2.77 \\
\hline 32 & 1.95 & 0.25 & 0.88 & 54 & 0.88 & 1.01 & 1.91 \\
\hline 33 & 1.94 & 0.36 & 0.99 & 55 & 1.82 & 0.27 & 1.04 \\
\hline 34 & 0.41 & 1.83 & 2.72 & 56 & 0.91 & 0.95 & 1.76 \\
\hline 35 & 1.56 & 0.30 & 1.10 & 57 & 1.61 & 0.55 & 1.38 \\
\hline 36 & 0.89 & 0.92 & 1.79 & 58 & 1.67 & 0.30 & 1.15 \\
\hline 37 & 1.86 & 0.45 & 1.15 & 59 & 1.23 & 0.77 & 1.66 \\
\hline 38 & 1.66 & 0.49 & 1.30 & 60 & 1.46 & 0.35 & 1.24 \\
\hline 39 & 1.99 & 0.52 & 1.12 & 61 & 2.04 & 0.60 & 0.72 \\
\hline 40 & 0.58 & 1.36 & 2.25 & 62 & 0.27 & 1.71 & 2.60 \\
\hline 41 & 2.04 & 0.82 & 0.90 & 63 & 0.97 & 0.83 & 1.70 \\
\hline 42 & 0.28 & 1.53 & 2.39 & 64 & 2.10 & 0.30 & 0.62 \\
\hline 43 & 1.99 & 0.44 & 1.03 & 65 & 1.83 & 0.16 & 0.96 \\
\hline 44 & 1.68 & 0.43 & 1.24 & 66 & 0.67 & 1.30 & 2.20 \\
\hline
\end{tabular}

Melakukan clustering objek dengan memasukkan setiap objek ke dalam cluster (grup) berdasarkan jarak minimumnya. Suatu data akan menjadi anggota dari suatu cluster $\left(\mathrm{C}_{1}, \mathrm{C}_{2}\right.$ maupun $\left.\mathrm{C}_{3}\right)$ yang memiliki jarak terkecil 
dari pusat cluster-nya [5]. Misalnya untuk data pertama, jarak terkecil ada pada cluster yang ke-2 yaitu 0.11, berarti mahasiswa pertama akan menjadi anggota pada kelompok cluster yang ke-2. Demikian juga untuk data yang kedua, jarak terkecil ada pada cluster yang ke-3 yaitu 0.82, berarti mahasiswa kedua akan menjadi anggota pada kelompok cluster yang ke-3. Posisi cluster setiap mahasiswa dapat dilihat pada Tabel II.

Daftar data posisi cluster pada Tabel III menunjukkan hasil pengelompokan dari proses perhitungan dari Tabel II, sehingga diperoleh hasil pengelompokan baru untuk dilakukan iterasi ke-2, dengan jumlah anggota cluster $\mathrm{C} 1$ sebanyak 21, C2 sebanyak 39 dan C3 sebanyak 6, dari total anggota cluster sebanyak 66.

TABEL III.

\begin{tabular}{cc}
\hline \hline $\begin{array}{c}\text { Mhs } \\
\text { ke }\end{array}$ & $\begin{array}{c}\text { Kelompok } \\
\text { Cluster }\end{array}$ \\
\hline 1 & C2 \\
2 & C3 \\
3 & C1 \\
4 & C1 \\
5 & C1 \\
6 & C2 \\
7 & C2 \\
8 & C3 \\
9 & C3 \\
10 & C2 \\
11 & C2 \\
12 & C3 \\
13 & C2 \\
14 & C2 \\
15 & C2 \\
16 & C1 \\
17 & C2 \\
\hline \hline
\end{tabular}

POSISI CLUSTER SETIAP MAHASISWA ITERASI KE-1

\begin{tabular}{|c|c|c|c|}
\hline $\begin{array}{c}\text { Mhs } \\
\text { ke }\end{array}$ & $\begin{array}{c}\text { Kelompok } \\
\text { Cluster }\end{array}$ & $\begin{array}{c}\text { Mhs } \\
\text { ke }\end{array}$ & $\begin{array}{c}\text { Kelompok } \\
\text { Cluster }\end{array}$ \\
\hline 18 & $\mathrm{C} 1$ & 35 & $\mathrm{C} 2$ \\
\hline 19 & $\mathrm{C} 2$ & 36 & C1 \\
\hline 20 & $\mathrm{C} 1$ & 37 & $\mathrm{C} 2$ \\
\hline 21 & C1 & 38 & $\mathrm{C} 2$ \\
\hline 22 & $\mathrm{C} 2$ & 39 & $\mathrm{C} 2$ \\
\hline 23 & $\mathrm{C} 2$ & 40 & C1 \\
\hline 24 & $\mathrm{C} 2$ & 41 & $\mathrm{C} 2$ \\
\hline 25 & $\mathrm{C} 1$ & 42 & $\mathrm{C} 1$ \\
\hline 26 & $\mathrm{C} 2$ & 43 & $\mathrm{C} 2$ \\
\hline 27 & $\mathrm{C} 1$ & 44 & $\mathrm{C} 2$ \\
\hline 28 & $\mathrm{C} 2$ & 45 & $\mathrm{C} 2$ \\
\hline 29 & $\mathrm{C} 2$ & 46 & C3 \\
\hline 30 & $\mathrm{C} 2$ & 47 & C1 \\
\hline 31 & C3 & 48 & C1 \\
\hline 32 & $\mathrm{C} 2$ & 49 & $\mathrm{C} 2$ \\
\hline 33 & $\mathrm{C} 2$ & 50 & $\mathrm{C} 2$ \\
\hline 34 & $\mathrm{C} 1$ & 51 & $\mathrm{C} 2$ \\
\hline
\end{tabular}

\begin{tabular}{cc}
\hline \hline $\begin{array}{c}\text { Mhs } \\
\text { ke }\end{array}$ & $\begin{array}{c}\text { Kelompok } \\
\text { Cluster }\end{array}$ \\
\hline 52 & $\mathrm{C} 1$ \\
53 & $\mathrm{C} 1$ \\
54 & $\mathrm{C} 1$ \\
55 & $\mathrm{C} 2$ \\
56 & $\mathrm{C} 1$ \\
57 & $\mathrm{C} 2$ \\
58 & $\mathrm{C} 2$ \\
59 & $\mathrm{C} 2$ \\
60 & $\mathrm{C} 2$ \\
61 & $\mathrm{C} 2$ \\
62 & $\mathrm{C} 1$ \\
63 & $\mathrm{C} 2$ \\
64 & $\mathrm{C} 2$ \\
65 & $\mathrm{C} 2$ \\
66 & $\mathrm{C} 1$ \\
\hline \hline
\end{tabular}

3) Langkah berikutnya menghitung pusat cluster baru

Pusat cluster baru ditentukan berdasarkan pengelompokan anggota dari masing-masing cluster. Berdasarkan Tabel III.3, cluster pertama $\left(\mathrm{C}_{11}\right)$ dengan parameter Nilai Rerata UN memiliki 21 anggota. Pusat cluster pertama yang baru dihitung berdasarkan rata-rata koordinat dari 21 anggota tersebut adalah:

$\mathrm{C}_{11}=(6.21+6.33+6.88+5.58+6.23+6.17+5.73+6.20+6.45+6.25+6.75+6.58+6.25+5.77+5.88+6.15+6.40$ $+6.85+6.60+6.23+6.67) / 21=5.98$

Cluster kedua $\left(\mathrm{C}_{12}\right)$ dengan parameter Nilai Rerata UN memiliki 39 anggota, sehingga pusat cluster kedua yang baru dihitung berdasarkan rata-rata koordinat dari 39 anggota tersebut, dengan total nilai 275.93 adalah:

$\mathrm{C}_{12}=275.93 / 39=7.08$

Cluster ketiga $\left(\mathrm{C}_{13}\right)$ dengan parameter Nilai Rerata UN memiliki 6 anggota, sehingga pusat cluster ketiga yang baru dihitung berdasarkan rata-rata koordinat dari 6 anggota tersebut, dengan total nilai 33.02 adalah:

$\mathrm{C}_{13}=33.02 / 6=5.50$

Pusat cluster baru untuk parameter IPK mahasiswa adalah:

$\mathrm{C}_{21}=45.08 / 21=2.15$

$\mathrm{C}_{22}=106.40 / 39=2.73$

$\mathrm{C}_{23}=19.28 / 6=3.21$

4) Ulangi iterasi yang dimulai dari langkah 2, sampai konvergen sehingga cluster yang baru memiliki nilai yang tetap (tidak mengalami perubahan).

\section{PEMBAHASAN}

Pada penelitian sebelumnya yang dilakukan oleh Syafrianto (2005), pada iterasi ke-4 dihentikan karena hasil perhitungan menunjukkan adanya angka pusat cluster yang sama. Hasil klusterisasi didapatkan 3 kelompok data, yaitu: (1) Mahasiswa dengan IPK rendah dan jarang ke perpustakaan, dengan pusat cluster (1.48, 1.4); (2) Mahasiswa dengan IPK cukup tinggi dan cukup sering pergi ke perpustakaan, dengan pusat cluster (3.35, 1.64); dan (3) Mahasiswa dengan IPK tinggi dan sering pergi ke perpustakaan, dengan pusat cluster(3.49, 3.5).

Sedang pada penelitian ini, pengulangan dihentikan pada iterasi ke-3 dan ke-4, karena hasil perhitungan menunjukkan adanya angka pusat cluster yang yang sama. Dari hasil perhitungan kelompok data mahasiswa D3 didapatkan 3 kelompok cluster yaitu :

1) Kelompok pertama yang memiliki pusat cluster $(6.30,1.87)$ dimaksudkan bahwa kelompok pertama adalah mahasiswa dengan Nilai Rerata $U N=6.30$ dan IPK $=1.87$. Dari hasil pengelompokan mahasiswa yang IPKnya antara 1.5 - 2.0 nilai masuknya Rerata UN-nya antara 6.0 - 7.0.

2) Cluster yang kedua memiliki pusat cluster $(6.70,2.77)$ dimaksudkan bahwa kelompok kedua adalah mahasiswa dengan Nilai Rerata UN 6.70 dan IPK 2.77, untuk mahasiswa yang IPKnya antara 2.5 - 3.0 nilai masuk Rerata UN-nya antara 7.0 - 8.0. 
3) Cluster yang ketiga memiliki pusat cluster $(5.66,3.12)$ dimaksudkan bahwa kelompok ketiga adalah mahasiswa dengan Nilai Rerata UN 5.66 dan IPK 3.12, bagi mahasiswa yang IPK-nya antara 3.0 - 3.5 nilai masuk Rerata $\mathrm{UN} \geq 8.0$.

Hasil perhitungan kelompok data mahasiswa S1 didapatkan 3 cluster, yaitu:

1) Cluster yang pertama memiliki pusat cluster $(6.45,1.78)$ dimaksudkan bahwa kelompok pertama adalah mahasiswa dengan Nilai Rerata UN $=6.45$ dan IPK $=1.87$. Dari hasil pengelompokan mahasiswa yang nilai $\mathrm{UN} \leq 6.50$ dan prestasi akademik mahasiswa dengan IPK $\leq 1.5$.

2) Cluster yang kedua memiliki pusat cluster (7.30, 2.59) dimaksudkan bahwa kelompok kedua adalah mahasiswa dengan Nilai Rerata $\mathrm{UN}=7.30$ dan IPK $=2.59$. Dari hasil pengelompokan mahasiswa yang nilai $6.50<\mathrm{UN} \leq$ 7.50 dan prestasi akademik mahasiswa dengan $1.5<$ IPK $\leq 2.5$.

3) Cluster yang ketiga memiliki pusat cluster $(8.19,3.31)$ dimaksudkan bahwa kelompok ketiga adalah mahasiswa dengan Nilai Rerata UN $=8.19$ dan IPK $=3.31$. Dari hasil pengelompokan mahasiswa yang nilai $\mathrm{UN}>7.50$ dan prestasi akademik mahasiswa dengan IPK > 2.5 .

Selanjutnya hasil proses pengelompokan berdasarkan nilai tersebut dikelompokkan lagi berdasarkan asal kota sekolahnya, untuk mengetahui lebih jauh apakah ada relasi antara prestasi mahasiswa terhadap sebaran asal kota sekolahnya.

Dari hasil pengelompokan mahasiswa jenjang Diploma-3 berdasarkan kota asal sekolah yang dibagi dalam 3 area, yaitu: DIY - Jateng, Jatim - Jabar, Luar Jawa, diperoleh rerata IPK sebagai berikut:

1) Wilayah DIY - Jateng, rerata IPK $=2.74$

2) Wilayah Jatim - Jabar, rerata IPK $=2.47$

3) Wilayah Luar Jawa, rerata IPK $=2.41$

Dari hasil pengelompokan mahasiswa jenjang S1 berdasarkan kota asal sekolah yang dibagi dalam 3 area, yaitu: DIY - Jateng, Jatim - Jabar, Luar Jawa, diperoleh rerata IPK sebagai berikut:

1) Wilayah DIY - Jateng, rerata IPK $=2.70$

2) Wilayah Jatim - Jabar, rerata IPK $=2.64$

3) Wilayah Luar Jawa, rerata IPK $=2.60$

Profil sampel data mahasiswa tahun angkatan 2014/2015 tersebut dapat disimpulkan bahwa kelompok mahasiswa dengan nilai rerata UN yang rendah memiliki pengaruh terhadap prestasi akademik mahasiswa yang rendah $(6.30,1.87)$ jenjang D-3 dan $(6.45,1.78)$ untuk jenjang S1, sedang nilai UN yang semakin tinggi maka prestasi akademik mahasiswa juga tinggi $(5.66,3.12)$ untuk jenjang D-3 dan $(8.19,3.31)$ untuk jenjang S1.

\section{A. Simpulan}

\section{SIMPULAN DAN SARAN}

Berdasarkan penelitian yang dilakukan, dapat disimpulkan bahwa algoritma K-Means bisa digunakan untuk mengelompokkan mahasiswa berdasarkan nilai UN dan IPK. Dari data yang dilatih, didapatkan 3 kelompok.

1) Kelompok data mahasiswa D3, meliputi:

a. Cluster yang pertama memiliki pusat cluster $(6.30,1.87)$;

b. Cluster yang kedua memiliki pusat cluster $(6.70,2.77)$; dan

c. Cluster yang ketiga memiliki pusat cluster $(5.66,3.12)$.

2) Kelompok data mahasiswa S1, meliputi:

a. Cluster yang pertama memiliki pusat cluster $(6.45,1.78)$;

b. Cluster yang kedua memiliki pusat cluster $(7.30,2.59)$; dan

c. Cluster yang ketiga memiliki pusat cluster $(8.19,3.31)$.

Dari hasil pengelompokan mahasiswa jenjang Diploma-3 berdasarkan kota asal sekolah yang dibagi dalam 3 area, yaitu: DIY - Jateng, Jatim - Jabar, Luar Jawa, diperoleh rerata IPK sebagai berikut:

1) Wilayah DIY - Jateng, rerata IPK $=2.74$

2) Wilayah Jatim - Jabar, rerata IPK $=2.47$

3) Wilayah Luar Jawa, rerata IPK $\quad=2.41$

Dari hasil pengelompokan mahasiswa jenjang S1 berdasarkan kota asal sekolah yang dibagi dalam 3 area, yaitu: DIY - Jateng, Jatim - Jabar, Luar Jawa, diperoleh rerata IPK sebagai berikut:

1) Wilayah DIY - Jateng, rerata IPK $=2.70$

2) Wilayah Jatim - Jabar, rerata IPK $=2.64$

3) Wilayah Luar Jawa, rerata IPK $\quad=2.60$

B. Saran

Untuk mengembangkan lebih jauh dari penelitian ini, disarankan untuk mengembangkan lebih lanjut adanya pemetaan kesesuaian antara prestasi akademik mahasiswa dikaitkan dengan asal jurusan dan prestasi di SMA/SMK. 


\section{REFERENSI}

[1] Arief Jananto," “Memprediksi kinerja mahasiswa menggunakan teknik data mining (studi kasus data akademik mahasiswa unisbank", Tesis Tidak Terpublikasi, Yogyakarta: Universitas Gajah Mada, 2010.

[2] Andina Budiarti, Yudho Giri Sucahyo, dan Yova Ruldeviyani, Studi karakteristik kelulusan peserta didik dengan teknik clustering”, Seminar Nasional Sistem dan Informatika, Bali, 2006.

[3] Andi Syafrianto, "Perancangan aplikasi K-means untuk pengelompokan mahasiswa STMIK EL-ERHAMA Yogyakarta berdasarkan frekuensi kunjungan ke perpustakaan dan IPK”, Yogyakarta: STMIK EL-ERHAMA, 2005.

[4] Efraim T., Decision support systems and intelligent systems, Edisi ke-7, Andi, Yogyakarta, 2005.

[5] Pramudyo, A. S., Case base reasoning untuk klasifikasi mahasiswa baru berdasarkan prediksi Indeks Prestasi semester I (studi kasus Program Studi Teknik Informatika Universitas Bina Darma Palembang), Tesis Tidak Terpublikasi, Yogyakarta: Universitas Gajah Mada, 2008.

[6] Heribertus Giyanto, , Penerapan algoritma clustering K-Means, K-Medoid, Gath Geva, Tesis Tidak Terpublikasi, Yogyakarta: Universitas Gajah Mada, 2008.

[7] Jiawei Han and Micheline Kamber, Data mining concepts and techniques second edition, San Francisco: Morgan Kauffman, 2001.

[8] Oyelade, Oladipupo, Obagbuwa, "Application of K-Menas clustering algorithm for prediction of students acaddemic performance”, International Journal of Computer Science and Information Security, Volume 7, 2010.

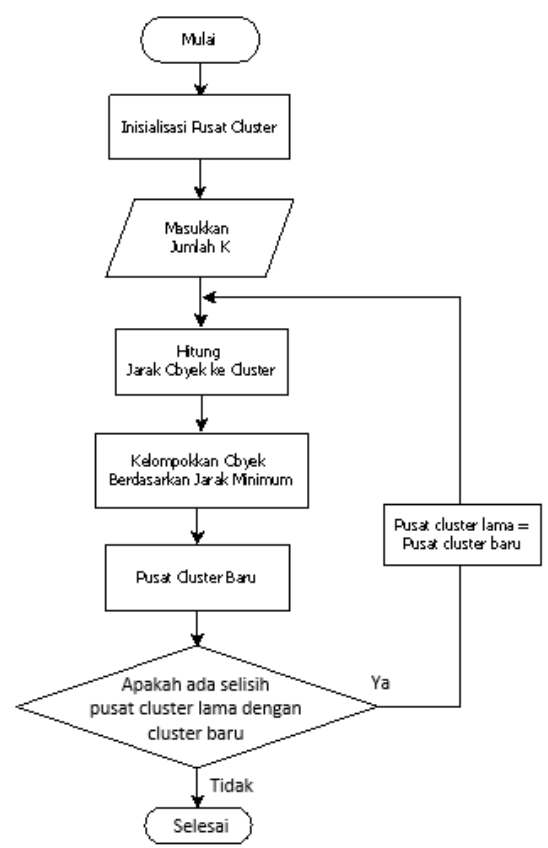

Gambar 5. Flowchart Metode K-Menas 